\title{
PENERAPAN MODEL PEMBELAJARAN KUANTUM DENGAN BANTUAN LKS UNTUK MENINGKATKAN PRESTASI BELAJAR IPA SISWA KELAS VI SEMESTER I SD NEGERI 4 TONJA TAHUN PELAJARAN 2016/2017
}

\author{
Oleh \\ Ni Made Rupini \\ SD Negeri 4 Tonja \\ nimaderupini18@gmail.com
}

\begin{abstract}
ABSTRAK
Penelitian ini dilaksanakan di SD Negeri 4 Tonja di Kelas VI semester I yang kemampuan siswanya untuk mata pelajaran IPA masih rendah. Tujuan penulisan penelitian tindakan kelas ini adalah untuk mengetahui apakah model pembelajaran Kuantum dapat meningkatkan prestasi belajar siswa. Metode pengumpulan datanya adalah tes prestasi belajar. Metode analisis datanya adalah deskriptif. Hasil yang diperoleh dari penelitian ini adalah model pembelajaran Kuantum dapat meningkatkan prestasi belajar siswa. Ini terbukti dari hasil yang diperoleh pada awalnya 61,45 pada siklus I menjadi 69,68 dan pada siklus II menjadi 78,94. Kesimpulan yang diperoleh dari penelitian ini adalah model pembelajaran Kuantum dapat meningkatkan prestasi belajar.
\end{abstract}

\section{Kata Kunci: Model Pembelajaran Kuantum, Prestasi Belajar, Belajar IPA}

\section{PENDAHULUAN}

Mata pelajaran IPA merupakan mata pelajaran yang mampu membantu peserta didik memiliki kemampuan serta keterampilan sesuai harapan apabila proses pembelajaran yang dilakukan tepat. Untuk itu sebagai seorang guru harus mampu membina peserta didiknya, mampu meningkatkan pengetahuan dan keterampilan, mampu meningkatkan keterampilan untuk meraih dan mengembangkan ilmu pengetahuan, teknologi dan seni, mampu mengembangkan penalaran dan sarana pemahaman beragam makna dalam menumbukan kemampuan peserta didiknya.

Agar tujuan tersebut dapat diupayakan, sebagai seorang guru harus memperlakukan siswanya sebagai individu yang memiliki kebutuhan dan minat, memberi kesempatan berpartisipasi secara komunikatif dalam berbagai macam aktivitas, mengupayakan agar memfokuskan pembelajaran kepada bentuk, keterampilan, mengupayakan agar materi yang diajar berkembang sesuai kehidupan siswa sehari-hari.

Pendidikan di sekolah memegang peranan penting dalam rangka mewujudkan tercapainya keberhasilan secara optimal seperti yang diharapkan. Proses belajar mengajar merupakan inti dari proses pendidikan. Dalam proses belajar mengajar tersebut guru menjadi pemeran utama dalam menciptakan situasi interaktif yang edukatif, yakni interaksi antara guru dengan siswa, siswa dengan siswa dan dengan sumber pembelajaran dalam 
menunjang tercapainya tujuan belajar.

Semua harapan atau das sollen yang disampaikan di atas merupakan kondisi yang diharapkan di pihak guru. Hal tersebut adalah tuntutan yang harus disampaikan dalam menulis latar belakang masalah.

Sebagai seorang guru yang profesional hendaknya dapat memilih dan menerapkan metode yang efektif agar materi yang dipelajari oleh siswa dapat dipahami dengan baik serta dapat meningkatkan prestasi belajar. Jika perlu variatif metode pembelajaran dapat diterapkan secara bersamaan untuk mendapatkan hasil yang maksimal dari pembelajaran. Untuk itu guru harus mempunyai kreatifitas dan inovasi baru dalam meningkatkan kemampuan dan teknik mengajarnya. Kemampuan teknik mengajar akan sangat berguma untuk membantu siswa mencapai tingkat ketuntasan belajar yang diharapkan.

Kenyataan yang di lapangan sangat jauh berbeda. Hasil yang diperoleh menyangkut penguasaan materi pelajaran IPA siswa kelas VI semester I SD Negeri 4 Tonja tahun Pelajaran 2016/2017 ternyata masih belum mencapai standar minimal seperti yang ditetapkan. Prestasi belajar mereka baru mencapai ratarata 61,45 yaitu di bawah KKM pada mata pelajaran IPA di sekolah ini yaitu 70,0 Daya serap siswa terhadap materi pelajaran IPA hanya $61,70 \%$ atau 29 siswa tergolong berhasil mencapai ketuntasan belajar sesuai yang diharapkan sementara 18 siswa atau 38,30\% tergolong tidak tuntas.

Kelemahan yang ada dapat diidentifikasi yaitu: rendahnya motivasi belajar siswa, rendahnya kemauan mereka untuk giat belajar karena mereka lebih senang bermain play station, kurangnya dorongan orang tua agar anak-anaknya giat belajar, model yang digunakan guru dalam mengajar lebih banyak ceramah.

Adapun langkah yang diambil untuk memperbaiki prestasi belajar siswa yaitu dengan tindakan perbaikan yang selanjutnya disusun dalam bentuk penelitian tindakan kelas dengan penggunaan model pembelajaran Kuantum dengan bantuan LKS untuk meningkatkan prestasi belajar IPA siswa kelas VI semester I SD Negeri 4 Tonja Tahun Pelajaran $2016 / 2017$. Dengan cara ini diharapkan peserta didik akan tertarik untuk berinteraksi dalam pembelajaran sehingga akan meningkatkan kemampuan dan keterampilannya.

Berdasarkan uraian di atas, judul yang diambil oleh peneliti dalam penelitian ini adalah Penerapan Model Pembelajaran Kuantum dengan bantuan LKS Untuk meningkatkan prestasi belajar IPA siswa kelas VI semester I SD Negeri 4 Tonja tahun Pelajaran 2016/2017.

\section{METODE PENELITIAN}

Tempat peneliti melakukan penelitian ada di SD Negeri Tonja Jalan Antasura 4x Kecamatan Denpasar Utara. Prosedur yang dilakukan dalam penelitian ini mengikuti alur gambar ahli yang dirujuk. Untuk itu Mulai dari ide umum. Ide itu dicek dan bila perlu dilakukan perbaikan-perbaikan, ditinjau lagi, dibuat perencanaan menyeluruh, dilakukan tindakan, dimonitor, dicari kebenarannya, dicek yang belum, baik untuk tindakan selanjutnya. Subjek penelitian ini adalah semua siswa 
kelasVI semester I SD Negeri 4 Tonja Tahun Pelajaran 2016/2017. Objek penelitian ini adalah peningkatan prestasi belajar IPA siswa kelas VI semester II SD Negeri 3 Tonja tahun pelajaran. 2016/2017 setelah diterapkan model pembelajaran kuantum dengan bantuan LKS dalam pembelajaran.

Penelitian ini dilakukan dari bulan januari sampai bulan Mei 2017. Data hasil yang akan diperoleh dalam penelitian ini terfokus pada sebuah. tes prestasi belajar. Metode yang digunakan untuk menganalisis data hasil penelitian ini adalah metode deskriptif kuantitatif. Data kuantitatif dianalisis dengan mencari mean, median, modus, membuat interval kelas dan melakukan penyajian dalam bentuk tabel dan grafik

\section{KAJIAN PUSTAKA Model Pembelajaran Kuantum}

Bobby DePorter, 1992 (dalam Udin Saifudin Sa'ud, 2008: 125) beranggapan bahwa metode belajar Kuantum sesuai dengan cara kerja otak manusia dan cara belajar manusia pada umumnya dengan model Super Camp yang dikembangkan bersama kawankawannya pada awal tahun 1980an, prinsip-prinsip dan model pembelajaran Kuantum menentukan bentuknya. Pembelajaran Kuantum berdasarkan pada landasan konteks yang menyenangkan dan situasi penuh kegembiraan.Model ini dicetuskan oleh seorang pendidik berkebangsaan Bulgaria yang bernama Georgi Lozanov yang melakukan uji coba tentang sugesti dan pengaruhnya terhadap hasil belajar, teorinya yang terkenal tersebut Suggostology. Menurut
Lazanov, pada prinsipnya sugesti itu mempengaruhi hasil belajar.

Kaifa, 1999 (dalam Udin Saifudin, 2008: 125) mengatakan bahwa pembelajaran Kuantum sebagai salah satu model, strategi dan pendekatan pembelajaran khususnya menyangkut keterampilan guru dalam merancang, mengembangkan dan mengelola sistim pembelajaran sehingga guru mampu menciptakan suasana pembelajaran yang efektif, menggairahkan dan memiliki keterampilan hidup. Selanjutnya Udin (2008: 126) mengatakan bahwa pembelajaran Kuantum sebagai salah satu alternatif pembaharuan pembelajaran, menyajikan petunjuk praktis dari spesifik untuk menciptakan lingkungan belajar yang efektif dan bagaimana menyederhanakan proses belajar sehingga memudahkan belajar siswa.

Selanjutnya Bobby DePorter, 1992 (dalam Udin Saifusin Sa'ud, 2008: 128-129) memberi penjelasan terhadap 2 hal yaitu: 1) prinsip dan strategi pembelajaran Kuantum dan 2) pengembangan strategi pembelajaran Kuantum.

1. Untuk prinsip dan strategi terdiri dari:

a. Segalanya berbicara, maksudnya bahwa seluruh lingkungan kelas hendaknya dirancang untuk dapat membawa pesan belajar yang dapat diterima oleh siswa, ini berarti rancangan kurikulum dan rancangan pembelajaran guru, informasi, bahasa tubuh, katakata, tindakan, gerakan dan seluruh kondisi lingkungan haruslah dapat berbicara membawa pesan-pesan belajar bagi siswa. 
b. Segalanya bertujuan, maksudnya semua penggubahan pembelajaran tanpa terkecuali harus mempunyai tujuan-tujuan yang jelas dan terkontrol. Sumber dan fasilitas yang terlihat dalam setiap pembelajaran pada prinsipnya untuk membantu perubahan perilaku kognitif, afektif dan psikomotor.

c.Pengalaman sebelum pemberian nama, maksudnya sebelum siswa belajar memberi nama (mendefinisikan, mengkonseptualisasi, membedakan, mengkatagorikan) hendaknya telah memiliki pengalaman informasi yang terkait dengan upaya pemberian nama tersebut.

d.Mengakui setiap usaha, maksudnya semua usaha belajar yang telah dilakukan siswa harus memperoleh pengakuan guru dan siswa lainnya. Pengakuan ini penting agar siswa selalu berani melangkah ke bagian berikutnya dalam pembelajaran.

e.Merayakan keberhasilan, maksudnya setiap usaha dan hasil yang diperoleh dalam pembelajaran pantas dirayakan. Perayaan ini diharapkan memberi umpan balik dan motivasi untuk kemajuan dan peningkatan hasil belajar berikutnya.

Selanjutnya Bobby DePorter (1992), sintak -sintak atau langkah model pembelajaran kuantum dengan sebutan TANDUR, yaitu:

a. Tumbuhkan, yaitu dengan memberikan apersepsi yang cukup sehingga sejak awal kegiatan siswa telah termotivasi untuk belajar dan memahami Apa Manfaatnya Bagiku (AMBAK). b. Alami, berikan pengalaman nyata kepada setiap siswa untuk mencoba.

c. Namai, sediakan kata kunci, konsep, model, rumus, strategi dan metode lainnya.

d. Demonstrasikan, sediakan kesempatan kepada siswa untuk menunjukkan kemampuannya.

e. Ulangi, beri kesempatan untuk mengulangi apa yang telah dipelajarinya, sehingga setiap siswa merasa langsung dimana kesulitan akhirnya datang kesuksesan, kami bisa bahwa kami memang bisa.

f. Rayakan, dimaksudkan sebagai respon pengakuan yang proporsional.

Dari semua paparan di atas ada banyak hal yang mesti diperhatikan dalam model pembelajaran Kuantum seperti membuat suasana belajar yang menggairahkan, mengupayakan agar lingkungan belajar mendukung, rancangan belajar yang dinamis, mengkomunikasikan tujuan, kukuh atas prinsip-prinsip keunggulan, meyakini kemampuan diri dan kemampuan siswa, menjaga komunitas belajar terus tumbuh, rasa simpati dan saling pengertian, suasana belajar yang riang dan menyenangkan, kemampuan guru menunjukkan ketauladan, guru selalu berpandangan positif pada siswa bahwa mereka mempunyai kemampuan lebih untuk berprestasi, seorang guru harus mampu mengetahui karakteristik siswa, guru harus mampu memotivasi, kemampuan guru memberikan penguatan baik verbal maupun non verbal, seorang guru mesti mempunyai kesenangan yang tinggi apabila siswanya mampu 
menguasai pembelajaran, bersamasama siswa gemar merayakan keberhasilan, selalu mengupayakan interaksi-interaksi antara siswa dengan materi, siswa dengan siswa maupun siswa dengan guru, mengaitkan pembelajaran dengan masa depan siswa, guru mampu menata lingkungan belajar bisa dengan menata tempat duduk, mengatur group-group tertentu, menggunakan media pendukung pembelajaran, musik yang menyenangkan, kemampuan guru untuk merubah perintah menjadi ajakan, menciptakan strategi agar siswa banyak menggunakan pikiran, melakukan tanya jawab, menumbuhkan minta dan perilaku yang baik, serta guru mesti selalu mengupayakan keterampilan hidup dan keterampilan sosial siswa.

Bobby (dalam H. Yatim Riyanto, 2009: 180) menggunakan teknik dan teknik lainnya karena semua itu selaras dengan kerja otak anda, dengan cara-cara terbaik anda, teknik tersebut telah teruji semua berhasil, berarti quantum leraning juga berhasil. Selanjutnya Udin Saifudin Sa'ud (2009: 127128), istilah quantum dipinjam dari dunia ilmu Fisika yang berarti interaksi yang mengubah energi menjadi cahaya.Maksudnya dalam pembelajaran

quantum, pengubahan bermacam-macam interaksi yang terjadi dalam kegiatan belajar.Interaksi-interaksi itu mengubah kemampuan dan bakat alamiah guru dan siswa menjadi cahaya yang bermanfaat bagi kemajuan mereka dalam belajar secara efektif dan efisien. Selain itu, adanya proses pengubahan belajar yang masih dengan segala nuansanya, penyertaan segala yang berkaitan, interaksi dan perbedaan yang memaksimalkan momen belajar, fokus pada hubungan di dalam lingkungan kelas, seluruhnya adalah hal-hal yang melandasi pembelajaran Kuantum. Ada dua konsep utama yang digunakan dalam pembelajaran Kuantum dalam rangka mewujudkan energi guru dan siswa menjadi cahaya belajar yaitu: percepatan belajar melalui usaha sengaja untuk mengikis hambatan-hambatan belajar tradisional dan fasilitas belajar yang berarti mempermudah belajar.

Apabila mampu melaksanakan pembelajaran yang dilakukan di atas, maka pembelajaran akan menjadi bermakna. Belajar yang bermakna menurut Trianto (2010: 28) merupakan suatu proses dikaitkannya informasi baru pada konsep-konsep relevan yang terdapat dalam struktur kognitif seseorang. Kebermaknaan belajar sebagai hasil dari peristiwa mengajar ditandai oleh terjadinya hubungan antara aspek-aspek, konsep-konsep, informasi atau situasi guru dengan komponenkomponen yang relevan di dalam struktur kognitif siswa. Proses belajar tidak sekedar menghafal konsep-konsep atau fakta-fakta belaka, tetapi merupakan kegiatan menghubungkan konsep-konsep untuk menghasilkan pemahaman yang utuh, sehingga konsep yang dipelajari akan dipahami secara baik dan tidak mudah dilupakan. Dengan demikian agar terjadi belajar bermakna maka guru harus selalu berusaha mengetahui dan menggali konsep-konsep yang telah dimiliki 
siswa dan membantu memadukannya secara harmonis konsep-konsep tersebut dengan pengetahuan baru yang akandiperoleh.

\section{Prestasi Belajar}

Prestasi belajar berasal dari kata "prestasi" dan "belajar".Prestasi berarti hasil yang telah dicapai sedangkan belajar adalah berusaha memperoleh kepandaian/ilmu (Depdiknas, 2011: 4).

Prestasi belajar IPA sama dengan prestasi belajar bidang studi yang lain merupakan hasil dari proses belajar siswa dan sebagaimana biasa dilaporkan pada wali kelas, murid dan orang tua siswa setiap akhir semester atau akhir tahun ajaran.

$$
\text { Djamarah }
$$
mendefinisikan prestasi belajar sebagai hasil yang diperoleh berupa kesan-kesan yang mengakibatkan perubahan dalam diri individu sebagai hasil dari aktivitas dalam belajar.Kalau perubahan tingkah laku adalah tujuan yang mau dicapai dari aktivitas belajar, maka perubahan tingkah laku itulah salah satu indikator yang dijadikan pedoman untuk mengetahui kemajuan individu dalam segala hal yang diperolehnya di sekolah. Dengan kata lain prestasi belajar merupakan kemampuankemampuan yang dimiliki oleh siswa sebagai akibat perbuatan belajar atau setelah menerima pengalaman belajar, yang dapat dikatagorikan menjadi tiga ranah, yakni ranah kognitif, afektif, dan psikomotor.
Dengan mengkaji hal tersebut di atas, maka faktor-faktor yang dapat mempengaruhi prestasi belajar menurut Purwanto (2000: 102) antara lain: (1) faktor yang ada pada diri organisme itu sendiri yang dapat disebut faktor individual, seperti kematangan/pertumbuhan,

kecerdasan, latihan, motivasi, dan faktor pribadi, (2) faktor yang ada diluar individu yang disebut faktor sosial, seperti faktor keluarga/keadaan rumah tangga, guru dan cara mengajamya, alat-alat yang dipergunakan dalam belajarmengajar, lingkungan dan kesempatan yang tersedia dan motivasi sosial. Dalam penelitian ini faktor ke 2 yaitu faktor yang dari luar seperti guru dan cara mengajarnya yang akan menentukan prestasi belajar siswa. Faktor psikologis antara lain: intelegensi, perhatian, minat, bakat, motif, kematangan, kesiapan. Faktor kelelahan antara lain: kelelahan jasmani dan rohani. Sedangkan faktor ekstern digolongkan menjadi tiga faktor yaitu: faktor keluarga, faktor sekolah, faktor masyarakat. Faktor keluarga antara lain: cara orang tua mendidik, relasi antara keluarga, suasana rumah tangga dan keadaan ekonomi keluarga. Faktor sekolah antara lain: metode mengajar, kurikulum, relasi guru dengan siswa, relasi siswa dengan siswa, disiplin sekolah, pelajaran dan waktu sekolah, standar pelajaran, keadaan gedung, metode belajar dan tugas rumah. Faktor masyarakat antara lain: kegiatan siswa dalam masyarakat, mass media, teman bergaul, bentuk kehidupan masyarakat. Peningkatan prestasi belajar yang penulis teliti dalam hal ini dipengaruhi oleh factor ekstern yaitu metode mengajar guru. 
Sardiman (1988: 25) menyatakan prestasi belajar sangat vital dalam dunia pendidikan, mengingat prestasi belajar itu dapat berperan sebagai hasil penilaian dan sebagai alat motivasi.Adapun peran sebagai hasil penilaian dan sebagai alat motivasi diuraikan seperti berikut.

Mohammad Surya (2004), mengatakan bahwa faktor-faktor yang mempengaruhi prestasi belajar dapat dilihat dari berbagai sudut pandang, antara lain dari sudut si pebelajar, proses belajar dan dapat pula dari sudut situasi belajar.

Dari uraian di atas, dapat disimpulkan bahwa prestasi belajar adalah hasil yang dicapai siswa setelah melakukan kegiatan belajar yang berbentuk angka sebagai simbol dari ketuntasan belajar bidang studi sejarah.Prestasi belajar ini sangat dipengaruhi oleh factor luar yaitu guru dan metode.Hal inilah yang menjadi titik perhatian peneliti di lapangan.

\section{Pembelajaran IPA}

Hakikat IPA Ilmu Pengetahuan Alam (IPA) berhubungan cara mencari tahu tentang alam secara sistematis, sehingga IPA bukan hanya penguasaan kumpulan pengetahuan berupa fakta-fakta, konsepkonsep, atau prinsip-prinsip saja tetapi juga merupakan proses penemuan. Pendidikan IPA diharapkan dapat menjadi wahana bagi peserta didik untuk mempelajari diri sendiri dan alam sekitar, serta prospek pengembangan lebih lanjut dalam menerapkannya di dalam kehidupan sehari-hari.. Pendidikan IPA diarahkan untuk inkuiri dan berbuat sehingga dapat membantu peserta didik untuk memperoleh pemahaman yang lebih mendalam tentang alam sekitar.. Di tingkat SD/MI diharapkan ada penekanan pembelajaran Salingtemas (Sains, lingkungan, teknologi, danmasyarakat) yang diarahkan pada pengalaman belajar untuk merancang dan membuat suatu karya melalui penerapan konsep IPA dan kompetensi bekerja ilmiah secara bijaksana. Pembelajaran IPA sebaiknya dilaksanakan secara inkuiri ilmiah/scientific inquiry untuk menumbuhkan kemampuan berpikir, bekerja, dan bersikap ilmiah serta mengkomunikasikannya sebagai aspek penting hidup. Pencapaian SK dan KD didasarkan pada pemberdayaan peserta didik untuk membangun kemampuan, bekerja ilmiah, dan pengetahuan sendiri yang difasilitasi oleh guru

\section{Ruang Lingkup IPA}

Ruang Lingkup Pelajaran IPA untuk SD/MI meliputi aspek-aspek berikut:

1. Makhluk hidup dan proses kehidupan, yaitu manusia, hewan, tumbuhan dan interaksinya dengan lingkungan, serta kesehatan

2. Benda/materi, sifat-sifat dan kegunaannya meliputi: cair, padat, dan gas

3. Energi dan perubahannya meliputi: gaya, bunyi, panas, magnet, listrik, cahaya dan pesawat sederhana 4. Bumi dan alam semesta meliputi: tanah, bumi, tata surya,dan bendabenda langit lainnya.

\section{Tujuan Pembelajaran IPA Tujuan mata pelajaran IPA SD}

1. Memperoleh keyakinan terhadap kebesaran Tuhan Yang Maha Esa berdasarkan keberadaan, keindahan, dan keteraturan alam ciptaan-Nya 
2. Mengembangkan pengetahuan dan pemahaman konsepkonsep IPA yang bermanfaat dan dapat diterapkan dalam kehidupan sehari-hari

3. Mengembangkan rasa ingin tahu, sikap positif dan kesadaran tentang adanya hubungan yang saling mempengaruhi antara IPA, lingkungan, teknologi, dan masyarakat

4. Mengembangkan keterampilan proses untuk menyelidiki alam sekitar, memecahkan masalah dan membuat keputusan

5. Meningkatkan kesadaran untuk berperanserta dalam memelihara, menjaga dan melestarikan lingkungan ala

6. Meningkatkan kesadaran untuk menghargai alam dan segala keteraturannya sebagai salah satu ciptaan Tuhan

7. Memperoleh bekal pengetahuan, konsep dan keterampilan IPA sebagai dasar untuk melanjutkan pendidikan ke SMP.

\section{LKS( Lembar kerja Siswa )}

Lembar Kerja Siswa (LKS) 1. Pengertian LKS. LKS sebenarnya merupakan bagian dari bahan ajar. Pada rencana penelitian ini LKS dikembangkan secara terpisah dengan buku ajar. LKS dikembangkan sesuai dengan langkah penerapan model Problem Based Learning (PBL). "Worksheets are materials by which students are given transaction steps regarding what they are supposed to learn. Also, they include activities which give the students main responsibility in their own learning". LKS adalah bahan yang diberikan kepada siswa mengenai langkah apa yang seharusnya mereka pelajari. Juga, termasuk kegiatan yang memberikan tanggung jawab utama kepada siswa dalam belajar secara mandiri (Kurt \& Akdeniz dalam Yildirim, 2011:

LKS sebagai pengontrol kegiatan yang akan lebih efisien dan sistematis dalam waktu karena siswa dapat lebih fokus pada hasil karya siswa. Selain itu, guru diharapkan dapat memberikan dorongan, motivasi, dan memfasilitasi sebagai rujukan ketika siswa membutuhkan. Ini dilakukan agar siswa lebih senang dalam mengerjakan dan hasil yang diharapkankan akan lebih optimal (Khateeb dan Idrees dalam

\section{HASIL PENELITIAN DAN PEMBAHASAN \\ Hasil Penelitian}

Suharsimi Arikunto, Suhardjono, Supardi (2006: 83) menyatakan bahwa, dalam menyampaikan hasil penelitian dan pembahasan, perlu menyajikan uraian masing-masing siklus dengan data lengkap mulai dari perencanaan, pelaksanaan, pengamatan dan refleksi yang berisi penjelasan tentang aspek keberhasilan dan kelemahan yang terjadi. Juga disampaikan kemajua) pada diri siswa, lingkungan, guru, motivasi dan aktivits belajar, situasi kelas dan hasil belajar, kemukakan grafik dan tabel hasil analisis data yang menunjukkan perubahan yang terjadi disertai pembahasan secara sistimatis dan jelas. 


\section{Siklus I}

\section{Pelaksanaan Tindakan I}

a. Sebelum memasuki ruangan kelas untuk memulai pelaksanaan tindakan pada siklus I ini guru selaku peneliti menyiapkan segala alat dan perlengkapan yang akan dibawa ke ruang kelas.

b. Sesampainya di kelas, guru selaku peneliti melaksanakan pembelajaran dengan pembelajaran pendahuluan yaitu: mengucapkan salam, melakukan absensi, memotivasi siswa agar giat belajar, melakukan apersepsi, menyampaikan tujuan pembelajaran serta cakupan materi yang sedang diajarkan.

\section{Refleksi Siklus}

Prestasi belajar siswa siklus

a. Rata-rata (mean)

Rumus yang digunakan untuk memperoleh nilai rata-rata kelas adalah $\frac{\text { Jumlahnilai }}{\text { Jumlah siswa }}=\frac{3.275}{47}=$ 69,68

b. Median (titik tengah)

Median yang diperoleh dari data siklus I dengan menggunakan cara tersebut adalah: .70

c. Modus (angka yang paling banyak/paling sering muncul)

Modus adalah angka yang paling banyak muncul dalam data yang sudah diperoleh. Dalam data hasil penelitian ini, angka yang paling banyak muncul adalah 70

Kekurangan-kekurangan/kelemahankelemahan yang ada dari pelaksanaan tindakan siklus I adalah:

1. Belum mampu memotivasi siswa untuk giat belajar

2. Masih konvensional, materi disajikan cepat, akibat siswa jumlahnya terlalu banyak
3. Belum menguasai model-model yang konstruktivis

4. Belum alamiah siswa belum mengalami langsung

5. Belum mampu merubah cara pengajaran menjadi pembelajaran, masih berpusat pada guru

Sedangkan kelebihan yang ditemukan pada pelaksanaan tindakan siklus I adalah:

a. Dapat membinbing siswa kearah berpikir yang sama dalam satu saluran pikiran ,

b. karena kuantum teaching lebih melibatkaan siswa, maka pada saat pembelajaran perhatian murid dapat dipusatkan pada halhal yang dianggap penting .

c. Siswa dirangsang untuk aktif dan lebih cepat mengerti

d. Pembelajaran yang diberikan guru mudah dimengerti oleh siswa

\section{Siklus II}

Perencanaan meliputi:

a) Guru selaku peneliti merencanakan untuk melakukan penelitian dari bulan Juli sampai bulan Nopember 2017 pada semester I.

b) Guru selaku peneliti merencanakan untuk memperbaiki prestasi belajar IPA yang masih di bawah KKM memanfaatkan model pembelajaran Kuantum

c) Untuk memperdalam pemahaman tentang model dan metode yang akan diterapkan, guru selaku peneliti melakukan pengkajian beberapa literatur yang sesuai dengan permasalahan yang akan diselesaikan.

d) Menyusun jadwal penelitian, materi, RPP, soal-soal sebagai 
instrumen untuk mengumpulkan data hasil penelitian.

1. Pelaksanaan Tindakan II

a. Sebelum memasuki ruangan kelas untuk memulai pelaksanaan tindakan pada siklus II ini guru selaku peneliti menyiapkan segala alat dan perlengkapan yang akan dibawa ke ruang kelas.

b. Sesampainya di kelas, guru selaku peneliti melaksanakan pembelajaran dengan pembelajaran pendahuluan yaitu: mengucapkan salam, melakukan absensi, memotivasi siswa agar giat belajar, melakukan apersepsi, menyampaikan tujuan pembelajaran serta cakupan materi yang sedang diajarkan.

\section{Observasi/Pengamatan Siklus I}

Hasil pengamatan pada siklus II penelitian sampaikan pada tabel berikut

\section{Refleksi Siklus I}

Analisis kuantitatif Prestasi belajar siswa siklus II

1. Rata-rata (mean) Perhitungan rata-rata dilakukan melalui penggunaan rumus sebagai berikut
http://ejournal.ihdn.ac.id/index.php/AW

$\frac{\text { Jumlah nilai }}{\text { Jumlah siswa }}=\frac{3,710 . .}{47 .}=78,94$

2. Median (titik tengah)

3. Median yang diperoleh dari data siklus II dengan menggunakan cara tersebut adalah: 80

4. Modus (angka yang paling banyak/paling sering muncul) 80

\section{Pembahasan Hasil yang Diperoleh dari Siklus I}

Hasil tes prestasi belajar yang merupakan tes hasil belajar memforsir siswa untuk betul-betul dapat memahami apa yang sudah dipelajari. Nilai rata-rata siswa di siklus I sebesar.69,68 menunjukkan bahwa siswa setelah menguasai materi yang diajarkan walaupun belum begitu sempurna. Hasil ini menunjukkan peningkatan kemampuan siswa menguasai mata pelajaran IPA Apabila dibandingkan dengan nilai awal siswa sesuai data yang sudah disampaikan dalam analisis sebelumnya.

Setelah dilakukan tindakan dalam dua siklus dapat dilihat perbandingan nilai rata-rata yang diperoleh, dimana pada awalnya nilai rata-rata siswa hanya 61,45 naik di siklus I menjadi 69,68 dan di siklus II naik menjadi 78,94 Kenaikan ini merupakan upaya maksimal yang peneliti laksanakan untuk meningkatkan prestasi belajar IPA siswa kelas VI Semester I terutama meningkatkan mutu pendidikan di SD Negeri 4 Tonja tahun Pelajaran 2016/2017

\section{SIMPULAN}

Dari data awal ada 18 siswa mendapat nilai di bawah KKM dan pada siklus I menurun menjadi 16 siswa dan siklus II hanya 0 siswa 
mendapat nilai di bawah KKM. Nilai rata-rata awal 61,45 naik menjadi 69,68 pada siklus I dan pada siklus II naik menjadi.78,94

Dari data awal siswa yang tuntas hanya 11 orang sedangkan pada siklus I menjadi lebih banyak yaitu 31 siswa dan

pada siklus II menjadi cukup banyak yaitu 47 siswa

Berdasarkan uraian diatas maka dapat disimpulkan Bahwa : Penerapan model Pembelajaran kuantum dengan batuan LKS dapat meningkatkan prestasi belajar IPA siswa kelas VI semester I SD Negeri 4 Tonja tahun Pelajaran 2016/2017

\section{DAFTAR PUSTAKA}

Arikunto, Suharsimi; Suhardjono; Supardi. 2006. Penelitian Tindakan Kelas. Jakarta: PT Bumi Aksara.

Depdikbud.1984/1985.Program Akta Mengajar $\quad V$-B Komponen Dasar Kependidikan: Penilaian Program Pendidikan. Jakarta: Universitas Terbuka.

Dimyati dan Mudjiono. 2001. Belajar dan Pembelajaran. Jakarta: Dirjen Dikti.

Djamarah, Syaful Bahri. 2002. Prestasi Belajar dan Kompetensi Guru. Surabaya: Usaha Nasional.

Gagne, Robert M. 1977. The Conditions of Learning. Third Edition. New York: Holt, Reinhart and Winston.

Gregory, Robert J. 2000. Psychological Testing:
History, Principles, and Applications. Boston: Allyn and Bacon

Hamalik, Oemar. 2002. Psikologi Belajar dan Mengajar. Bandung: Sinar Baru.

Nur, Mohamad et al. 2001. Teori Belajar. Surabaya: University Press.

Sardiman, A.M. 1988. Interaksi dan Motivasi Belajar-Mengajar Pedoman bagi Guru dan Calon Guru. Jakarta: Rajawali Pers.

slameto. 2000. Belajar dan FaktorFaktor yang Mempengaruhinya. Jakarta: Rineka Cipta.

Suryabrata, Sumadi. 2000. Pengembangan Alat Ukur Psikologis. Yogyakarta: Penerbit Andi.

Slamet, PH. 2004. MBS, Life Skill, KBK, CTL dan Saling Keterkaitannya.Makalah yang Disampaikan pada Semiloka DBEP di NTB dan Bali.

Saifudin Sau'd, Udin. 2008. Inovasi Pendidikan. Bandung:

Alfabeta.

Trianto.2010. Mengembangkan Model Pembelajaran Tematik. Jakarta: Prestasi Pustaka 